\title{
How the Impact of Work Discipline, Work Environment and Transformational Leadership on Employee Performance: A Study at Japanese Automotive Dealer
}

\author{
Agus Arijanto \\ Lecturer of Economic and Business Faculty in Universitas Mercu Buana Jakarta and Student of Postgraduate \\ Program, Doctor of Management Science, Universitas Jenderal Soedirman Purwokerto \\ Siti Zulaikha Wulandari \\ The Senior Lecturer and Associate Professor in Postgraduate Program of Doctor in Management Science, \\ Universitas Jenderal Soedirman Purwokerto Central Java
}

\begin{abstract}
This research is aim to know the working discipline, transformational leadership and the work environment impact on employee performance at automobile dealer. This research was conducted towards the 62 respondents using a quantitative approach assosiatif. The data analysis used are outer and inner model models using SEM Model . The results showed the work discipline, work environment and transformational leadership have a positive and significance impact on the performance of employees,
\end{abstract}

DOI: $10.7176 / \mathrm{EJBM} / 11-36-02$

Publication date: December $31^{\text {st }} 2019$

\section{INTRODUCTION}

Trade service companies need to maintain the quality of human resources so that the services provided remain good and consistent with their customers. Human resources are the most important assets in the company, to realize the company's goals. Applying the right business strategy is largely determined by the quality of human resources who play an important role in the company's operational activities, planning and implementing established business strategies. Of the importance of human resources, human resource management is created or better known as HR. According to Mangkunegara (2015: 2) human resource management is a planning, organizing, coordinating, implementing, and controlling the procurement, development, remuneration, integration, maintenance, and separation of workers in order to achieve organizational goals. Human resources are the most important factor in every activity of an organization or company. The importance of human resources in carrying out an effective and efficient work mechanism, due to the leaders and employees are the subjects in every activity of a company. Human resources have a major role in every activity of the company. Human resources in the company need to be managed professionally in order to create a balance between the needs of employees with the demands and capabilities of the company. This balance is the company's main key to developing productively (Mangkunegara, 2015: 1). One of the factors that can support these problems is employee performance. This is needed to know about how to manage employees to work well that can be meet to the company goals. To create company goals, employees are required to be obedient to the rules, excel and skilled. Therefore, companies need to manage human resources properly, because human resources are the key in successfully achieving company goals. This automobile dealer company is a car dealer that was founded in 1974 and has nine branches in Indonesia, its name as PT. Astrido Prima Mobilindo (APM) serves sales of new cars, periodic driving services and sells auto parts and leasing facilities (financing) for the purchase of new cars on credit. This company detected a lot of employees found that the level of performance has decreased or the effectiveness of the performance of employees has decreased ultimately impacting on the progress of the company. In 2018, the target of sales has been reached by the company.

Table 1.1 The Summary of Sales Achiement in January 2018 to march 2018

\begin{tabular}{|l|l|c|c|}
\hline No & Month & Sales per /unit & Slaes Target /unit \\
\hline 1. & January & 55 & 62 \\
\hline 2. & February & 51 & 65 \\
\hline 3. & March & 50 & 68 \\
\hline
\end{tabular}

Source : PT. APM - Branch of Kamal, 2018

According to table 1.1 there is a decrease in sales each month from the specified target. In January as many as 56 units, this achievement did not meet the specified sales target of 62 units, in February as many as 55 units, this achievement did not meet the specified sales target of 65 units. And in March as many as 53 units, this achievement did not meet the sales target of 68 units. The decline in sales of PT. APM - Branch of Kamal refers to employee performance factors, one of which is the level of delay and absenteeism. According to Afandi (2016: 68) performance is the work that can be achieved by a person or group of people in a company in 
accordance with the authority and responsibilities of each in an effort to achieve company goals. The following is a data description of the delay and absence (alpha) of PT. APM - Branch of Kamal.

Picture 1.1

The level of delay and absence of PT. APM - Branch of Kamal Period January 2018 - March 2018

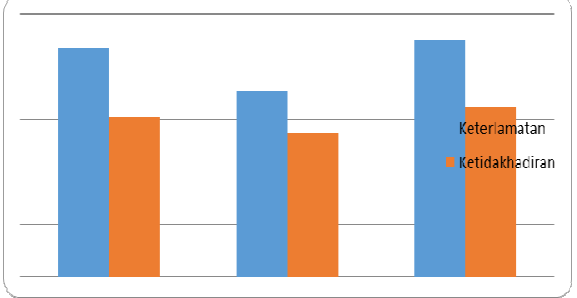

Source : PT. APM - Branch of Kamal, 2018

According to the figure 1.1 in January 2018, $\backslash$ the delay of PT. APM - Branch of Kamal $43.50 \%$ and absent employees (alpha) 30.60\%, in February 2018 the delay of PT. APM - Branch of Kamal decreased by $8 \%$ to $35.50 \%$ and absent employees (alpha) decreased by $3.2 \%$ to $27.40 \%$, while in March 2018 the delay of PT. APM - Branch of Kamal increased by $9.7 \%$ to $45.20 \%$ and absent employees (alpha) increased by $4.9 \%$ to $32.30 \%$. It can be concluded that the performance of the employees of PT. APM - Branch of Kamal is not yet optimal. With this problem the researchers conducted a pre-survey of the employees of PT. APM about factors that can improve employee performance.

Figure 1.2

Employee Performance in Pre-Survey
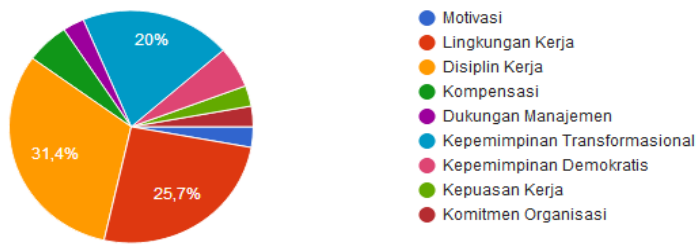

Source : PT. APM - Branch of Kamal, 2018

According to the picture 1.2 above the employees of PT. APM - Branch of Kamal answered the presurvey, found that factors of work discipline, work environment and transformational leadership can improve employee performance. With an increase in these factors, employees can improve their performance to the company, so that it can bring the company to be able to survive in the competition. One of the factors that influence the level of success of an organization is to pay attention to Work Discipline. Work discipline on employees is important in achieving company goals and can improve employee performance. Discipline is an attitude of awareness in complying with applicable company regulations. Without a disciplined attitude, the company will hardly manage its employees. With a high work discipline attitude, it will improve employee performance and improve work performance achieved. According to Hamali (2018: 214) discipline implies an attitude of respect for company rules and regulations, which are in employees, which causes employees to voluntarily adjust to company rules and regulations. Employees who often violate or ignore company regulations mean that employees have poor work discipline. Employees who are subject to company regulations and regulations illustrate the existence of good discipline. Next Pre Survey employee work discipline at PT. APM.

Table 1.2

The result of Pre-Survey to Work Dicipline PT. APM

\begin{tabular}{|c|l|c|c|}
\hline No & \multicolumn{1}{|c|}{ Yes } & No \\
\hline \multicolumn{1}{|c|}{ Statement } & 15 & 20 \\
\hline 1 & I always arrive on time & 14 & 21 \\
\hline 2 & I'm asking for permission when it's too late & 15 & 20 \\
\hline 3 & I'm asking for permission when I don't sign in & & \\
\hline
\end{tabular}

Source : PT. APM, 2018

According to table 1.2 out of 35 respondents as many as 15 respondents answered yes I always arrive on time, 20 respondents answered not coming on time, out of 35 respondents as many as 14 respondents answered yes I asked for permission when arriving late and 21 respondents answered no permission when arriving late, from 35 respondents as many as 15 respondents answered yes I asked for permission when not entering and 20 respondents answered no permission when not entering. It can be concluded that work discipline is decreasing, without the discipline, all activities that will be carried out will create unsatisfactory results and not in accordance with company expectations. One of the factors that influence the level of success of an organization 
is to pay attention to the work environment. According to Romli (2014: 81), the work environment is the overall work facilities and infrastructure around employees who are doing work that can affect the implementation of work. This work environment includes the place of work, facilities and job aids, cleanliness, lighting, tranquility, air temperature as well as the working relationship between people who are in the place. According to Chandrasekar's research in Antara (2015) states that the work environment influences performance employees where inconvenience that occurs at work can result in increased employee error rates which will further affect employee performance. Companies need to pay attention to the work environment around their employees so that they can support employees to carry out the tasks assigned. Researchers conducted a pre-survey of how the work environment at PT. APM, can be seen in table 1.3 as follows:

Tabel 1.3 The result of Work Enviroment Pre-Survey at PT. APM

\begin{tabular}{|l|l|c|c|}
\hline No & \multicolumn{1}{|c|}{ Statement } & Yes & No \\
\hline 1. & I feel the temperature in the room makes me comfortable & 11 & 24 \\
\hline 2. & I can work together as a team & 14 & 21 \\
\hline 3. & I feel that the lighting in the workspace does not interfere with my work & 21 & 14 \\
\hline
\end{tabular}

According to table 1.3 out of 35 respondents as many as 11 respondents answered yes I feel the temperature in the room has made me comfortable and 24 people feel the temperature in the work room does not make it comfortable, of the 35 respondents as many as 14 respondents can work in teams and 21 people cannot work in teams, of 35 respondents as many as 21 respondents answered that the lighting in the workspace did not interfere with my work and 14 respondents said no lighting in the workspace disturbed my work. Then it can be concluded that the work environment of PT. APM is not conducive. Another factor that can improve employee performance is the attitude of leadership, success or failure of the company is also very much determined by leadership. Attitudes that fully support employees to work, motivate and provide vision and mission to employees. The characteristics of these leaders are transformational leaders. According to Munawaroh in Apriyanto and Satrio (2015) suggested that transformational leadership is described as a leadership style that can arouse or motivate employees, so that they can develop and achieve performance at a high level, more than what they had previously predicted. Transformational leadership is an effective style to improve the performance of its employees. With transformational leadership, followers of a transformational leader feel trust, admiration, loyalty, and respect for the leader, and they motivate to do more than was originally expected of them (Yukl, 2013: 316). Without the attitude of leadership then the company difficult to achieve the objectives to be achieved. PT. APM also needs to have a leadership attitude that is able to support the performance of its employees so that activities in the company can run optimally. Previous researchers conducted a pre-survey of employees and found that there were problems in PT. APM, can be seen in table 1.4 as follows:

Tabel 1.4 The Result of Transformational Leadership Pre-Survey at PT. APM

\begin{tabular}{|l|l|l|l|}
\hline No & \multicolumn{1}{|c|}{ Statement } & Yes & No \\
\hline 1. & My leader motivates me to work & 12 & 23 \\
\hline 2. & The leader paid attention to the problems I faced & 9 & 26 \\
\hline 3. & My leader puts pressure on work & 25 & 10 \\
\hline
\end{tabular}

Source : PT. APM, 2018

According to table 1.4 as many as 35 respondents 12 respondents answered yes my leader motivated at work and 23 respondents answered no my leader motivated at work, out of 35 respondents 9 respondents answered the leader gave attention to the problems I faced and 26 respondents answered the leader did not pay attention to the problem I face, out of 35 respondents 25 respondents answered that my leadership put pressure on work and 10 respondents said no leadership did not put pressure on work. It can be concluded that transformational leadership at PT. APM that employees do not get the attention of the leadership of the problems at hand. Employees who feel pressure from the leader and lack of attention and support usually experience a decrease in their enthusiasm for work, which can lead to decreased employee work. Employees can improve their performance by how leaders treat employees, provide support, pay attention and provide solutions to employees if they are experiencing problems that are being faced. According to the description above, researchers are interested in knowing deeply about the influence of work discipline, work environment and transformational leadership on employee performance at this company.

\section{Literature Review}

Human Resource Management

Definition of Human Resource Management Human Resource Management has a very important role for a company where human resources regulate and manage the course of productivity in the company. This is supported by Mulyadi (2016: 89) human resource management (HRM) has an important role, among others, regulating and determining employee work programs that include several important aspects, among others, determining the quantity and quality and assigning workforce so that activities can be effective and efficient in 
accordance with company goals that have been made in the work plan or work program. According to Hamali (2018: 2) human resource management was created to form a proper company culture and include programs that describe and support the core values of the company and ensure its success. Human resource management according to Edison et al (2017: 10) human resource management is management that focuses on maximizing the ability of employees or their members through various strategic steps in order to improve employee performance towards optimizing company goals.

According to Wirawan (2015: 21) is a functional management of human resources - part of the overall management of a company that manages people who work for the company to be able to create economic and social value effectively and efficiently in achieving corporate goals. It can be concluded that human resource management is a series of employee activities that can realize a goal that has been determined by the company.

b. Human Resource Management Function

According to Hasibuan in Mulyadi (2016: 90) stated that there are eleven functions in human resource management, among others:

1. Planning : Planning (Human Resources Planning) is to plan the workforce effectively and efficiently to suit the needs of the company in helping the realization of goals. Planning is done by setting staffing programs. The staffing program covers the organization, direction, control, procurement, development, compensation, integration, maintenance, discipline, and termination of employees. A good staffing program will help the achievement of company, employee and community goals.

2. Organizing: Organizing is an activity to organize all employees by determining the division of labor, delegation of authority, integration, and coordination in the organization chart. The organization is only a means to an end. With a good organization will help realize the objectives effectively.

3. Direction : Directing (Directing) is an activity that leads all employees, so that all work effectively and efficiently in helping the achievement of company goals, employees, and the community. Leadership is carried out by the leader by assigning subordinates to do all their duties properly.

4. Control : Controlling is the activity of controlling all employees to obey company regulations and work according to plan. If there are irregularities or mistakes, corrective actions are carried out and the plan is completed. Employee control includes attendance, discipline, behavior, cooperation, implementation of work, and maintaining the work environment situation.

5. Procurement : Procurement is a process of withdrawal, selection, placement, orientation, and induction to get employees in accordance with company needs. Good procurement will help realize the company's goals.

6. Development : Development (Development) is a process of improving technically, theoretically, conceptually, and morally employees through education and training. The education and training provided must be in accordance with current and future employment needs.

7. Compensation : Compensation is the direct and indirect compensation of money or goods in return for services provided to the company. The principle of compensation is fair and appropriate. Fair is interpreted in accordance with work performance, feasible is interpreted as being able to meet needs and is guided by the government minimum wage limit and based on consistent internal and external.

8. Integration : Integration (Integration) is an activity to unite and the needs of employees in order to create harmonious and mutually beneficial cooperation. The company makes a profit, employees can meet the needs of the results of their work. Integration is important and difficult in human resource management because it brings together two opposing interests.

9. Maintenance : Maintenance (Maintanance) is an activity to maintain and improve the physical, mental and loyalty of employees, so that they will continue to work together until retirement, good maintenance is carried out with welfare programs based on the needs of most employees and based on consistent internal and external.

10. Discipline : Discipline is the most important human resource management function and the key to the realization of goals, because without discipline it is difficult to realize the maximum objectives. Discipline is the desire and awareness to obey company rules and social norms.

11. Termination : Termination (determination) is the termination of one's employment relationship from the company. This dismissal is caused by an employee's wishes, the company's wishes, the employment contract expires, retirement and other reasons

The Purpose of Human Resource Management

According to Hamali (2018: 15) the goal of human resources not only reflects the will of senior management, but must also balance the challenges of the organization, the function of human resources and influential people. Human resource management contains the following four objectives:

a) Social Purpose : The social goal of human resource management is that organizations or companies are socially and ethically responsible for the needs and challenges of society by minimizing their negative 
impacts. Business organizations or companies are expected to improve the quality of society and help solve social problems.

b) Organizational Objectives : Organizational goals are formal goals that are made to help the organization achieve its goals. The human resources division was formed to help managers realize the goals of the organization.

c) Functional Purpose : The Functional Purpose is a goal to maintain the contribution of the human resources division at a level that is appropriate to the needs of the organization. The human resources division must improve human resource management by providing good consultation.

d) Individual goals : Individual goals are the personal goals of each member of the organization or company to be achieved through its activities in the organization. Employees will leave the company if personal and organizational goals are not harmonious.

Work Discipline

Work discipline is the level of compliance and obedience to the rules in force and is willing to accept sanctions or penalties for violating the rules set out in the discipline (Fahmi 2016: 75). According to Afandi (2016: 1) work discipline is a tool used by managers to change behavior and as an effort to increase one's awareness and willingness to obey all company regulations and applicable social norms. According to Hamali (2018: 214) Work discipline is a strength that develops in the body of employees and causes employees to voluntarily adjust to the rules, and the high values of work and behavior. According to Hasibuan (2017: 193) work discipline is the awareness and willingness of a person to obey all company regulations and applicable social norms. According to Wirawan (2015: 279) one of the behaviors that affects its performance is its work discipline. Discipline behavior is the behavior of employees who meet the standards of behavior, codes of conduct, work regulations, work operating procedures established by the company. It can be concluded that work discipline is a process of employee training to shape employee behavior or attitude in complying with applicable regulations in the company so that activities within the company can run effectively.

The Affect's Factors of Work Discipline

According to Sutrisno in Hamali (2018: 219) that the factors of influence to employee on work discipline are :

a) The size of the compensation : the size of the compensation can affect the establishment of discipline. Employees will comply with all applicable regulations, if employees feel they are guaranteed a compensation that is worth the effort they have contributed to the company.

b) The presence or absence of leadership in the company, a leadership model is very important, because in a company environment, all employees will always pay attention to how the leader can enforce his discipline and how the leader can control himself from words, actions, and attitudes that can harm the established discipline rules.

c) The presence or absence of definite rules that can be used as a handle: coaching discipline will not be carried out in the company, if there are no definite written rules to be able to hold together. Discipline is not possible to enforce if the rules made are only based on verbal instructions that can change according to conditions and situations.

d) Courage of the leader in taking action : the courage of the leader to take action is very necessary when there is an employee who violates discipline in accordance with the level of violation he made.

e) The presence or absence of leadership supervision : the person who best carries out supervision of this discipline is certainly the direct supervisor of the employees concerned. This is due to the direct superiors who know best and are closest to the employees who are underneath.

f) There is no concern for employees : the successful leaders who give great attention to employees will be able to create good work discipline. A leader is not only close to the meaning of physical distance, but also has a close distance in the inner sense.

g) Created habits that support the establishment of discipline, including:

1. Mutual respect when meeting work environment.

2. Give praise in accordance with the place and time so that employees will also feel proud of the praise.

3. Often involving employees in meetings let alone meetings related to the fate and work of employees.

4. Tells colleagues if they want to leave a place, by informing where and for what business, even though subordinates.

Implementation of Work Disciplinary Sanctions

According to Mangkunegara (2016: 131) the implementation of sanctions against disciplinary offenders by giving a warning, must be immediate, consistent, and impersonal.

1. Warning : Employees who violate work discipline need to be given a first, second and third warning letter. 
The purpose of giving a warning is so that the employee in charge is aware of the violation he has committed. Besides that the warning letter can also be taken into consideration in providing an assessment of employee conditions.

2. Imposition of Sanctions Must Be Immediate : Employees who violate discipline must be immediately sanctioned in accordance with applicable company regulations. The goal is that employees who have an understanding understand the sanctions for violations in force in the company. Failure to impose sanctions will weaken the existing discipline. Besides that, it gives opportunity for violators to ignore company discipline.

3. Sanctions Must Be Consistent : Imposing sanctions for undisciplined employees must be consistent. It aims to make employees aware and respect the regulations that apply to the company. The inconsistency of sanctions can result in employees feeling employee discrimination, the ease of sanctions and the neglect of discipline.

4. Sanctions Must Be Personal : Sanctions for disciplinary violations must not discriminate between employees, young and old, men and women still being treated in accordance with applicable regulations. The aim is for employees to realize that work discipline applies to all employees with violation sanctions in accordance with applicable regulations in the company.

Employees who have high work discipline will find it risky to leave work if it is not finished, even will feel happy if it can finish on time, he has a target in completing a job so that always prioritize which work needs to be completed first.

\section{Dimensions in Work Discipline}

According to Handoko in Hamali (2018: 216) dimensions and indicators of work discipline consist of :

a) Preventive Discipline : preventive discipline is an activity carried out to encourage employees to follow various standards and rules, so that deviations can be prevented. The main goal is to encourage employee self-discipline. Preventive discipline maintains employee self-discipline not solely because it is forced by company management.

b) Corrective Discipline : corrective discipline is an activity taken to deal with violations of the rules and try to avoid further violations. Corrective activities are often in the form of punishment and are called disciplinary actions, for example actions can be in the form of warnings or suspension. The goals of disciplining in brief are as follows: (1) To correct violators. (2) To prevent other employees from carrying out similar activities.(3) To keep the various group standards consistent and effective.

c) Progressive Discipline :the company can implement a progressive discipline policy, which means giving heavier penalties for repeated violations. The aim is to give employees the opportunity to take corrective action before more serious penalties are carried out. Progressive discipline also allows management to help employees correct mistakes.

\section{Work Environment}

a. Definition of work environment

According to Afandi (2016: 52) work environment is everything that exists around employees that can affect employee job satisfaction in carrying out their work so that maximum work results will be obtained, where in the work environment there are work facilities that support employees in completing tasks that are charged to employees to improve employee work in a company. According to Sedarmayanti in Lubis (2015) states that the work environment is the overall tools and materials faced, the surrounding environment in which a person works, his work methods, and work arrangements both as individuals and as a group can be concluded that good work environment conditions will support employee productivity which in turn has an impact on increasing the level of employee performance. According to Widayati, Catur C. at all. (2019). Universitas Mercu Buana Jakarta, The Effect of Job Satisfaction and Job Enviroment on. 1(December), 1-16, the working environment of is a very important part of the component when employees perform work activities. By paying attention to a good working environment or creating working conditions that are able to provide motivation to work, it will bring influence to the enthusiasm or spirit of employees in the work While the work environment according to Nitisemito in Sunyoto (2015: 38) is everything that exists around the employees and that can affect him in carrying out the tasks that are charged, such as cleanliness, music, lighting, and others. It can be concluded that the work environment is everything that exists around employees both from the facilities provided and the relationships between employees that are well established, so that employees can carry out their activities and can improve their performance.

Types of Work Environment

According Sedarmayanti in Lubis (2015: 38) states that in general the type of work environment is divided into 
two namely the physical work environment and non-physical work environment.

a) The physical work environment is all physical forms that exist around the workplace that can affect employees directly or indirectly. The environment that is directly related to employees is the work center, tables, chairs and so forth. While the intermediary environment or general environment can also be called a work environment that affects the human condition such as temperature, humidity, air circulation, lighting, noise, mechanical vibrations, odor, color and others. To be able to minimize the influence of the physical environment on employees, the first step must be to study humans both about their physical and behavioral as well as their physical behavior and then to use them as a basis for thinking about the appropriate physical environment.

b) Non-physical work environment is all conditions that occur relating to work relationships both relationships with superiors and fellow colleagues or relations with subordinates.

\section{Transformational Leadership}

According to Robbin in Sudaryono (2017: 177) transformational leadership is a leader who devotes his attention to the problems faced by his followers by giving encouragement and encouragement to achieve his goals. According to Bass in Wirawan (2017: 141) the term transformational leadership is an effort by leaders to transform followers from one low level of need to another higher level of need. According to Yukl (2015: 326) transformational leaders are leaders who do more things that will empower followers and make them less dependent on leaders such as delegating great authority to several people, developing the skills and selfconfidence of followers, creating self-managing groups itself, provides direct access to sensitive information, eliminates unnecessary control, and builds a strong culture to support empowerment. According to Sudaryono (2017: 179) transformational leadership defines the need for change, creates new visions, mobilizes commitment to carry out the vision and transforms followers at both the individual and organizational level. It can be concluded that transformational leadership is giving attention to employees, and motivating employees to achieve the goals set. According to Anik Herminingsih and Supardi. (2017) Universitas Mercu Buana Jakarta, The Effects of Work Ethics, Transformational and Transactionalv Leadership on Work Performance of Teachers. Management Studies, 5(3), 250-261. The transformational leadership called moral values of followers in an attempt to increase their awareness of Ethical issues and to mobilize their energies and resources to reform institutions.

While transactional leadership style according to Burn in Yukl (2010,p.290) is a leadership that motivates follower transaction by calling their personal interest. Transformational leadership is based on the conceptual richness, through charisma, individualized consideration, and intellectual stimulation, is believed to be able to bring ideas to reach into the future, the principles of democracy and transparency. Therefore, it needs to be adopted into the leadership of the principal, in particular in order to support school-based management or forms of other educational reforms. Changes in the centralization policy into decentralization, make the school havea more significant role in determine its discretion.

\section{Principles of Transformational Leadership}

According to Sudaryono (2017: 181) there are seven principles for creating transformational leadership, namely :

a) Simplification, the success of leadership begins with a vision that will be a mirror and a common goal.

b) Motivation, the ability to get commitment from everyone involved with the vision that has been explained is the second thing that needs to be done. When a transformational leader can create a synergy in the organization, it means he can also optimize, motivate and energize each of his followers.

c) Facilitation, in terms of the ability to effectively facilitate learning that takes place within the organization institutionally, in groups or individually.

d) Innovation, which is the ability to boldly and responsibly make changes when needed and become a demand for the changes that occur.

e) Mobility, which is the mobilization of all available resources to complement and strengthen everyone involved in achieving their vision and goals.

f) Standby, which is the ability to always be ready to learn about themselves and welcome change with a positive new paradigm.

g) Determination, that is unanimous determination to always arrive at the end of a unanimous determination to get things done properly and thoroughly.

Characteristics of Transformational Leaders

According to Tichy and Devana in Wirawan (2017: 149) stated the characteristics of transformational leaders, namely:

1. Identifying itself as an agent of change. Based on design or opportunity, they are responsible for leading the company throughout the transformation. They articulate themselves as taking on the role of agents of 
change with attractive self-concepts.

2. Courageous Individuals. In the behavior of courage there is an intellectual component and an emotional component. Intellectually a brave person has a perspective that can confront reality even if it is not pleasant. Emotionally can state the truth to others who might not want to hear about it.

3. They believe in people. Transformational leaders are not dictators. They are very powerful, they are sensitive to others, and they strive to empower others. They understand and use the principles of motivation, emotions, pain, trust, and loyalty. To empower someone they often use humor, symbolism, rewards and punishment.

4. They are attractors of value. Each transformational leader is able to elaborate on a set of core values and show behavior in accordance with his position.

5. They are lifelong learners. All transformational leaders are able to talk about the mistakes they make. However, they do not see the failure as a failure but as a learning experience.

6. They have the ability to deal with complexity, ambiguity, and uncertainty. Every transformational leader is able to face problems in a complex and changing world.

7. They are visionary. Transformational leaders can dream, are able to describe dreams and images so people share them.

Components of Transformational Leadership

According to Bass and Avolio in Sudaryono (2017: 178) mentions four components of transformational leadership, namely :

1) Idealized influence. Leaders who have charisma show their position, emphasize trust, put themselves on difficult issues, show the most important values, emphasize the importance of goals, commitments, and the ethical consequences of decisions, and have a vision and awareness of mission. Thus the leader will be emulated, arousing pride, loyalty, respect, enthusiasm and trust of subordinates. In addition, leaders will make subordinates have confidence.

2) Inspiration motivation. Leaders have an interesting vision for the future, setting high standards for subordinates. Optimistic and enthusiastic, giving encouragement and meaning to what needs to be done. So this kind of leader will increase the optimism and enthusiasm of subordinates and motivation and inspire subordinates to exceed motivational expectations through emotional support and emotional appeal.

3) Intellectual stimulation (intellectual stimulation). Leaders who encourage subordinates to be more creative, eliminate the reluctance of subordinates to express ideas and solve problems by using new approaches that use intelligence and rational reasons rather than based solely on opinion or estimation.

4) Individualized consideration. The leader is able to treat others as individuals, consider individual needs and aspirations, listen, educate and me

Employee Performance

Definition of Employee Performance Performance is the result achieved by someone according to the measurement that applies to the work in question. A person's performance can be seen through their activities in carrying out daily work. This activity illustrates how he strives to achieve the goals set (Sudaryono 2017: 67). According to Bastian in Fahmi (2015: 2) states that performance is a picture of the level of achievement of the implementation of an activity or program in realizing the goals, objectives, mission and vision of the organization as outlined in the formulation of a strategic plan (strategic planning) of an organization. According to Priansa (2018: 269) performance is the result of work achieved by employees in developing tasks and jobs that come from the organization. And the definition according to Riniwati (2016: 167) performance is a combination of ability, opportunity and effort obtained from a work. Performance is a record obtained or generated from the activities of employees who carry out their activities that are carried out within a certain period. Meanwhile, according to Wirawan (2015: 238) the term performance is an abbreviation of kennik work energy that is human energy if it is put on or employed will produce work output. It can be concluded that performance is the level of achievement or results achieved by employees in carrying out their duties. According to Gibson, Ivancevich and Donnely in Priansa (2018: 270) states that the factors that influence employee performance are individual variables, psychological variables and organizational variables.

1) Efforts that can be made to improve performance can be done in ways as below according to (Priansa 2017: 54):

2) Discrimination : A manager must be able to distinguish objectively between employees who can make important contributions to company goals and employees who cannot make important contributions. Performance appraisal is carried out to find this out. Through performance appraisal, measurable and fair decisions can be made, for example relating to employee development, payroll, and so on.

3) Giving Hope : in general, employees who have high performance expect a variety of recognition from the company, both recognition from the material side, the internal social side of the company, and certain 
career paths in accordance with the company's capabilities. For this reason, the company must be able to conduct proper identification to ensure that employees who perform well have a variety of expectations that are important to themselves so that they are motivated to realize the best performance and the company ensures that the employee's expectations can be given in accordance with employee desires.

4) Development : efforts to improve employee performance can also be designed in employee development schemes that are in accordance with employee performance. Employees who produce high performance can be promoted according to company needs and adjusted to employee performance, while employees who have performance under the provisions, refreshing training programs are needed to break the deadlock, while increasing employee performance.

5) Communication : managers are responsible for evaluating the performance of employees and accurately communicating their assessments. To do this accurately, managers must know the shortcomings and problems faced by employees and how to overcome them. In addition, managers also need to know the training and development programs needed. To ensure that managers need to communicate intensely with employees.

\section{Performance assessment}

According to Afandi (2016: 72) performance appraisal is to find out how productive an employee is and whether he can work together or more effectively in the future, so that employees and companies benefit.

Performance evaluation according to Mathis and Jackson in Fahmi (2015: 65) is a process of evaluating how well employees do their work when compared to a set of standards, and then communicating that information. Meanwhile, according to Wirawan (2015: 239) performance evaluation as a process of assessing valuing performance in a certain time by comparing its performance with its performance standards and the results are used to make human resource management decisions regarding valuation.

Purpose of Performance Assessment

According to Werther and Davis in Priansa (2018: 272) states that some of the objectives of implementing employee performance appraisal by the company are: (1) Performance Improvement The performance appraisal results allow managers and employees to take actions related to performance improvement. (2) Compensation Adjustment The results of the performance appraisal help the decision makers to determine who is entitled to receive a raise or vice versa.(3) Placement Decision The results of the performance appraisal provide input on promotions, transfers, and demotion for employees.(4) Training and Development Needs

\section{Employee Performance Criteria}

According to Schuler and Jackson in Priansa (2017: 49) mentions three criteria related to performance, namely as follows :

1) Nature : criteria based on the nature of focusing on the personal characteristics of an employee. Loyalty, reliability, communication skills, and leadership skills are qualities that are often assessed during the assessment process. This type of criterion focuses on the way a person works, not on what is achieved or not achieved by someone in his work.

2) Behavior : behavioral criteria are focused on the way work is done. This criterion is very important for jobs that require personal relationships between employees. For example, whether the employees are friendly or pleasant.

3) Results : the criteria regarding results are increasingly popular as international productivity and competitiveness are increasingly emphasized. This criterion is focused on what has been achieved or produced rather than how something was achieved or produced.

\section{Benchmark Performance}

To get optimal employee contributions, companies must deeply understand strategies for managing, measuring and improving performance, which starts first by setting performance benchmarks. According to Afandi (2016: 69) there are several conditions for good performance benchmarks, namely : (1) Good benchmarks, must be able to be measured in a way that can be trusted. (2) Good benchmarks, must be able to distinguish individuals according to their performance (3) Good benchmarks, must be sensitive to input and actions from position holders.(4) Good benchmarks must be accepted by individuals who know their performance is being assessed.

\section{Performance Measurement}

According to Mondy, et al in Priansa (2018: 271) states that performance measurement can be done using dimensions :

1) Quantity of Work: The quantity of work is related to the volume of work and work productivity produced by employees within a certain period of time. 
2) Quality of Work : the quality of work is related to the consideration of accuracy, precision, neatness, and completeness in handling tasks within the company.

3) Independence (Dependability) : independence regarding the degree of employee's ability to work and develop tasks independently by minimizing the assistance of others.

4) Initiative (Intiative) : the initiative deals with the consideration of independence, thinking flexibility, and willingness to accept responsibility.

5) Adaptabilitywith regard to the ability to adapt considers the ability to react to changing needs and conditions.

6) Cooperation deals with consideration of the ability to cooperate, and with others. assignements, including whether to work overtime with all my heart.

Hypothesis

H1 : Work discipline has a positive and significant effect on the performance of employees of PT. APM

$\mathrm{H} 2$ : The work environment has a positive and significant effect on the performance of the employees of PT.APM

H3 : Transformational leadership has a positive and significant effect on the performance of employees of PT. APM

\section{III.Research Design}

The research design used in this study uses quantitative research methods with associative problem formulation. According to Sugiyono (2014: 13) quantitative research methods can be interpreted as research methods based on the philosophy of positivism, used to examine certain populations or samples, sampling techniques are generally carried out randomly, data collection using research instruments, data analysis is quantitative or statistics for the purpose of testing predetermined hypothesis. While the formulation of associative problems according to Sugiyono (2014: 55) is a research question that is asking the relationship between two or more variables.

\section{Variable Operations}

According to Sugiyono (2014: 58) variables are everything in the form of what is determined by researchers to be studied so that information is obtained about it, then conclusions are drawn. Variables according to Priyatno (2009) in Haryono (2017: 27) are concepts whose values vary or change. There are several types of variables as follows:

a. Independent (Exogenous) variables are variables that affect endogenous variables.

1) Work Discipline (X1)

According to Hamali (2018: 214) Work discipline is a strength that develops in the body of employees and causes employees to voluntarily adjust to the rules, and the high values of work and behavior.

2) Work Environment (X2)

According to Sedarmayanti in Lubis (2015: 35) states that the work environment is the overall tools and materials faced, the surrounding environment in which a person works, the method of work, and work arrangements both as individuals and as a group can be concluded that good working environment conditions will support employee productivity which in turn has an impact on increasing the level of employee performance.

3) Transformational Leadership (X3): According to Sudaryono (2017: 179) transformational leadership defines the need for change, creates a new vision, mobilizes commitment to carry out

vision and transform followers at both the individual and organizational level.

Research Population

According to Sugiyono (2014: 115) population is a generalization area that consists of objects or subjects that have certain qualities and characteristics determined by researchers to be studied and then conclusions drawn. The population in this study was 62 people consisting of 1 branch head, $1 \mathrm{CRO}, 1 \mathrm{SPV}$ Sales, $1 \mathrm{ADH}, 1 \mathrm{Head}$ of Workshop, 35 Marketing Divisions, 4 Administration Divisions, 8 Service Divisions.

\section{Research Samples}

According to Sugiyono (2014: 116) the sample is part of the number and characteristics of the population. If the population is large, and researchers may not study everything in the population, for example because of limited funds, manpower and time, then researchers can use samples taken from that population. The sampling used in this study uses Nonprobability Sampling. Nonprobability Sampling according to Sugiyono (2014: 120) is a sampling technique that does not provide equal opportunity or opportunity for each element or member of the population to be selected as a sample. For sample techniques using saturated sampling. According to Sugiyono 
(2014: 122) saturation sampling is a sampling technique when all members of the population are used as samples. The sample used in this study is all employees of PT. APM Brach of Kamal as many as 62 respondents.

\section{IV . Discussion of Research Results}

Effect of Work Discipline on Employee Performance

Work discipline has an original sample value of 0.142 , t-statistic $2.008>1.96$ and p-value $0.023<0.05$, then $\mathrm{H} 1$ is accepted, which means work discipline has a positive and significant effect on employee performance. This study is in accordance with Ferawati (2017) the results of work discipline research have a positive effect on employee performance. Firmness is also needed by the company to decide what sanctions will be given by employees. Sanctions are provided not only for employees who arrive late or return before working hours end. Sanctions also apply to employees who cannot complete their work on time. Supervisors who have conducted stricter supervision without being supported by employee awareness of work discipline, there will continue to be violations that will later have an impact on employee performance. The work discipline of the employees of PT. Astrido Prima Mobilindo-Daihatsu Kamal has a positive and significant effect on employee performance. Employees who have work discipline can improve their performance, such as carrying out tasks in a timely manner, completing work targets set by the company and arriving always on time and the company can give awards to employees who have a disciplined attitude at work so that employees can be enthusiastic and disciplined at work so the results of work can also be increased, on the contrary if the employees do not have the work discipline of the company can provide strict sanctions to employees who violate company rules.

\section{Effect of Work Environment on Employee Performance}

The work environment has an original sample value of 0.158 , t-statistic $2.677>1.96$ and p-value $0.004<0.05$, then $\mathrm{H} 2$ is accepted, which means the work environment has a positive and significant effect on employee performance. This study is in accordance with Yualiana (2017) work environment and a significant positive effect on employee performance. The work environment is the entire tool and tools around the place where people work, their work methods, and their work arrangements as individuals or groups. At PT. Astrido Prima Mobilindo-Daihatsu Kamal work environment is very important to help someone work well. A working environment is said to be good conditions such as a comfortable work environment, adequate air circulation, adequate facilities for working employees, good relations with colleagues and leaders can improve employee performance otherwise if the work environment is uncomfortable, the facilities do not support employees to work as well as not having a good relationship with colleagues or with leaders such as being unable to cooperate with the team, not being able to respect the opinions of others so that it can reduce employee performance, the company needs to improve the work environment within the company, which in turn employees feel comfortable and enthusiastic about working.

\section{The Effect of Transformational Leadership on Employee Performance}

Transformational leadership has a value of 0.720 , t-statistic $9.949>1.96$ and p-value $0.000<0.05$, then $\mathrm{H} 3$ is accepted, which means transformational leadership has a positive and significant effect on employee performance. This study is in accordance with Caillier (2014) the results of transformational leadership research affect employee performance. Evidence of this finding is strong enough that transformational leadership is very important for companies. Transformational leaders motivate employees to improve performance by providing training or development programs. Transformational Leadership PT. Astrido Prima Mobilindo-Daihatsu Kamal influences employee performance. Transformatioanal leadership that can provide support or motivation to employees fairly does not favor can improve employee performance otherwise if the leader does not provide support or motivation can reduce employee performance

\section{IV.Conclusion and Suggestion}

According to the results of the discussion this study tries to analyze variables related to work discipline, work environment, transformational leadership and employee performance. The results of this study were obtained from the employees of PT. APM, Branch of Kamal. From the research results obtained from the calculation of Partial Least Square (PLS), the following conclusions can be drawn :

1. Work discipline has a positive and significant effect on the performance of the employees of PT. APM, meaning that if good work discipline, employee performance in the company will improve.

2. The work environment has a positive and significant effect on the performance of the employees of PT. APM, meaning that if the work environment is good then the performance of employees in the company will improve.

3. Transformational leadership has a positive and significant effect on the performance of the employees of PT. Astrido Prima Mobilindo-Daihatsu Kamal, meaning that if transformational leadership is good, employee performance in the company will improve 
Suggestion

According to the above conclusions, it can be put forward some suggestions that are taken into consideration for this company as follows:

a) According to the results of the description of respondents' answers can be seen from the lowest average value of the variable work discipline with a mean value of 4.081 in the statement "I arrived on time". Therefore a suggestion that can be taken into consideration is that it is expected that the company needs to improve the work discipline of the employees of this company by giving strict sanctions to undisciplined employees and giving awards to employees who have a good level of discipline can also improve employee performance.

b) According to the results of the description of respondents' answers can be seen from the lowest average value of the work environment variable with a mean value of 3,839 in the statement "The color of my workspace is bright". Therefore, suggestions that can be taken into consideration are expected that the company can replace paint with bright colors so as to provide comfort for employees of this company.

c) According to the results of the description of respondents' answers can be seen from the lowest average value of the transformational leadership variable with a mean value of 3,565 in the statement "My leader has an interesting idea for the future". Therefore, suggestions that can be taken into consideration are expected leaders invite each employee discuss in solving problems so that they get new ideas. Thus it is expected to improve employee performance in accordance with company goals.

d) According to the results of the description of respondents' answers can be seen from the lowest average value of the variable employee performance with a mean value of 2.984 in the statement "I finish the job neatly". Therefore, suggestions that can be taken into consideration are expected to be able to re-evaluate every employee's work tasks. Thus it is hoped that employees can work neatly

\section{References}

Adityawarman, Yudha, Bunasor Sanim and Bonar M Sinaga. (2015). Effect of Workload on Employee Performance. Journal of Management and Organization, 6 (1), 35.

Afandi, Pandi. (2016). Concept \& Indicator Human Resources Management for Management Research. Yogyakarta: Deepublish.

Anik Herminingsih, \& Widienti Supardi. (2017). The Effects of Work Ethics, Transformational and Transactional Leadership on Work Performance of Teachers. Management Studies, 5(3), 250-261. https://doi.org/10.17265/2328-2185/2017.03.009

Antara, I Ketut. Kusuma Yogi. (2015). Effects of Leadership, Physical Work Environment, and Compensation on the Performance of UD.Terus Employees in Bali. Journal of Management, Business Strategy and Entrepreneurship, 9 (2), 163.

Anwar, Moh, Muhammad Nurul Qadri and Umi Kalsum. (2018). The Influence of Transformational Leadership, Work Discipline and Work Morale on Member Performance in Unit I Hubdam VII / Wirabuana. Sigma: Journal of Economic and Business, 1 (1).

Apriyanto, Wawan and R. Budhi Satrio. (2015). The Effect of Transformational Leadership Style and Work Motivation on Employee Performance. Journal of Management Science and Research, 4 (11).

Caillier, James. Gerard (2014). Toward a Better Understanding of the Relationship Between Transformational Leadership, Public Service Motivation, Mission Valence, and Employee Performance: A Preliminary Study. Public Personnel Management, 43 (2).

Chandra, Teddy and Priyono. (2016). The Influence of Leadership Styles, Work Environment and Job Satisfaction of Employee Performance - Studies in the School of. International Education Studies, 9 (1).

Edison, Emron., Anwar, Yohny., \& Komariyah, Imas. (2017). Human Resource Management Strategies and Changes in Order to Improve Employee and Organizational Performance. Bandung: Alfabeta.

Fahmi, Irham. (2015). Performance Management Theory and Applications. Bandung: Alfabeta.

Fahmi, Irham. (2016). Human Resource Management Theories and Applications. Bandung: Alfabeta.

Ferawati, Aphia. (2017). Effect of Work Environment and Work Discipline on Employee Performance. AGORA, 5 (1).

Ghozali, Imam. (2015). Partial Least Squares Concepts, Techniques and Applications Using the SmartPLS 3.0 Program. Semarang: Diponegoro University Semarang.

Ghozali, Imam., \& Kusumadewi, K. A. (2016). Structural Equation Model PLS-PM (Partial Least Square Path Modeling) RCACCA (Regularized Generalized Canonical Correlation Analysis). Semarang: Primary Yoga.

Hakam, Malik, Sudarsono and Abdul Hoyyi. (2015). Path Analysis of Factors Affecting the Cumulative Achievement Index (GPA) of UNDIP Statistics Students. Gaussian Journal Vol.4, 61-70.

Hamali, Arif. Yusuf. (2018). Understanding of Human Resource Management Strategies for Managing Employees. Yogyakarta: CAPS.

Haryono, Siswoyo. (2017). SEM Method for Management research of AMOS LISREL PLS. East Jakarta: 
Luxima Metro Media.

Hasibuan, S P. Malayu. (2017). Human Resources Management Revised Edition. Jakarta: Earth Literacy.

Kusuma, Galan and Edy Rahardja. (2018). Effect of Transformational Leadership Style, Organizational Culture and Work Motivation on Employee Performance (Study of PD BPR BKK Taman Pemalang Employees). Diponegoro Journal OF Management, 7 (2).

Lubis, Aswadi. (2015). A Conducive Work Environment And Factors That Influence It. AL-MASHARIF, 3 (1). Mangkunegara, Prabu. Anwar (2016). Corporate Human Resource Management. Bandung: Teen Rosdakarya.

Mardana, Fauzi. Yose, Harlen and H.B Isyandi. (2015). Analysis of the Effect of Motivation, Ability and Work Discipline on Employee Performance at PT. Bank Riau Kepri Batam Branch. Journal of Boxing Business Management, 7 (1).

Mulyadi. (2016). Introduction to Management. Bogor: IN MEDIA.

Priansa, Donni. June. (2017). Staffing Performance Management. Bandung: Loyal Reader.

Priansa, Donni. June. (2018). HR Planning \& Development. Bandung: Alfabeta.

Son, I Kadek. Andika Pramana and Made Subudi. (2015). The Effect of Transformational Leadership Style and Physical Work Environment on Employee Performance of PT BPR PEDUNGAN. Eud Management Journal, 4 (10).

Rifa'i and Jumiati Sasmita. (2015). The Effect of Work Discipline, Leadership and Motivation on Employee Performance of the Pulp Production Section at PT. Riau Pulp Pangkalan Kerinci Pelalawan Riau. Journal of Boxing Business Management, 7 (1).

Riniwati, Harsuko. (2016). Human Resource Management Main Activities and HR Development. Malang: UB Press.

Riyanto, Setyo, Ady Sutrisno, and Hapzi Ali. (2017). The Impact of Working Motivation and Working Environment on Employees Performance on the Indonesia Stock Exchange. International Review of Management and Marketing, 7 (3).

Romli, Khomsahrial. (2014). Complete Organizational Communication Revised Edition. Jakarta: Grasindo. Samson, Gitahi Njenga, MainaWaiganjo and Joel Koima. (2015). Effect of Workplace Environment on the Performance of Commercial Banks Employees in Nakuru Town. International Journal of Managerial Studies and Research, 3 (12).

Sudaryono. (2017). Introduction to Theory and Case Management. Yogyakarta: CAPS.

Sugiyono (2014). Business Research Methods. Bandung: Alfabeta.

Suharyanto, Ery Nugraha and Hendra Permana. (2014). The Effect of Compensation and Work Environment on the Employee Performance of the QIP Division of PT. GSI Co.

Widayati, C. at all. (2019). The Effect of Job Satisfaction and Job Enviroment On Turnovern Inttetnion 1(December), 1-16. https://doi.org/10.31933/DIJDBM 